4th International Scientific Conference SEC-IASR 2019, Galati, Romania, 7th - 8th June, 2019

\title{
Practicing Sports in Romania at the School Level
}

\author{
Marin CHIRAZI \\ https://doi.org/10.18662/lumproc/sec-iasr2019/11
}

How to cite: Chirazi, M. (2020). Practicing Sports in Romania at the School Level. In S. Marin \& P. Moisescu (vol. eds.), Lumen Proceedings: Vol. 12. 4th International Scientific Conference SEC-IASR 2019 (pp. 90-96). Iasi, Romania: LUMEN Publishing House. https://doi.org/10.18662/lumproc/sec$\underline{\text { iasr2019/11 }}$ 


\title{
Practicing Sports in Romania at the School Level
}

\author{
Marin CHIRAZI ${ }^{1}$
}

\begin{abstract}
One of the peculiarities of the physical education and sports education in Romania is the existence of the sportive sports education: Sports High Schools (which have classes beginning with the gymnasium cycle), sports classes (grades I-XII) in different schools (in particular in the theoretical schools) and the additional sports education represented by the Scholar Sports Clubs (CSS) and the Children's Palace (PC). The statistical analysis, carried out as a result of attempts to optimize the education of physical education and sports, has highlighted the fact that the most practiced sports are athletics (in all counties - 42), football (41), handball (41) followed by volleyball (34) and basketball (31). Having a very large area of distribution, we could call them national sports although national and international results are far from justifying the large amounts of money allocated. But here's a list of funded sports and "exotic" sports such as yachting and softball, baseball, hockey on the grass, ski jumping.

The last centralization requested by the Ministry of National Education (2015) resulted in a number of 70,102 sports students enrolled in both LPS and CSS. These students are enrolled in 2345 norms supported by 1937 titular teachers with specific specialty.

Although the number of athletes may seem high, it represents $2.19 \%$ of the total number of pupils in Romania (about 3.2 million).
\end{abstract}

Keywords: children; sport; organization; statistics.

\footnotetext{
${ }^{1}$ University "Alexandru Ioan Cuza" from Iasi, Romania, chirazim@,yahoo.com 


\section{Introduction}

Physical culture was considered a novelty in the interwar period, spread across all social classes [1]. The specificity of the discipline Physical education in this period is the attempt to put the individual in the service of the state and to combat moral deviations. A specific element of that period is the different goals between physical education for boys and girls, both of which aim to form healthy citizens, boys have to be prepared for military service, and girls for maternity [2]. The practice of sport in Romania, in the opinion of most specialists, athletes or former practitioners, should be subsidized entirely by the state budget as it was before 1990. A statistical analysis of the sports structures and not only as well a minimal historical study shows that in fact the budget allocation is much higher than it would be at first sight.

\section{Theoretical BackgroundContextul teoretic}

After World War II, physical education becomes a discipline with a well-defined status at all age levels. One characteristic of the period is the propagandistic character attributed to the discipline, by the possibility of obtaining international results demonstrating the superiority of the newly established Communist regime to the capitalist one. In this respect, between 1950 and 1970, at least one School Sports Club is set up in most of the larger cities in Romania and sports classes begin from primary to secondary [3].After 1990, after the fall of the Communist regime from the leadership, a new structure with a physical education profile was set up, namely Sports High Schools. These structures provided 8-10 hours of training in the curriculum and less hours in other subjects (general education) [4].

\section{Argument of the paper}

One of the peculiarities of the physical education and sport education in Romania is the existence of the sportive sports education: Sports High Schools (which have classes beginning with the gymnasium cycle), the existence of sports classes (from the 1st to the 12th grade) in different schools especially in the theoretical schools) and the supplementary sports education represented by the Sports School Clubs (CSS) and the Children's Palace (PC) [5]. The last two structures represent organizational forms similar to any school (didactic rules, management structures, auxiliary staff) but the presence of the students is optional (and where there are too 
many requests, selections are made - in recent years the interest is lower). The difference between the two school structures is given by funding arrangements. Schools with Sports Program receive funding from the Ministry of Public Finance through their city halls and CSS and PCs are funded directly by the Ministry of National Education, having as intermediate the County School Inspectorates. The school curriculum in the integrated sports education covers the same amount of hours as in the ordinary schools; only 8 hours per week are allocated for the specialty classes and 2 more at the school's decision. In other words, a student in such a class has to attend a 10-hour week at the sports discipline in which he enrolls in the gymnasium cycle and 10 or 12 hours at the level of high school [6].All LPSs have classes structured on sports disciplines (egg. handball girls, handball boys) and classes with several sport disciplines - mosaic classes. Students enrolled participate in the classes allocated to the disciplines in the common trunk after which each student has to undertake the sports training lesson.

\section{Arguments to support the thesis}

LPS as well as CSS must legitimate all students enrolled in sports federations and participate in competitions organized by them.

CSS have a number of norms in the organizational chart, and coaching teachers have to train beginners, advanced and performance groups. The number of students in these groups varies from one sport to another between 12 and 25 (handball) for beginners and 8 to 20 for performance groups [7]. Participants in a large variety of sports (Table 1) may be enrolled and allowed to participate in the training classes of the maximum age group corresponding to the end of the 12th grade. The most serious problem faced by CSS is the lack of children's interest in practicing sport and the lack of interest of parents to guide and support children in attending training.

As a result of the decision to reduce the money allocation from the state budget in 2018 it was partially merged (experimental in some counties) CSS so that there is only one structure in each county residence city (41 + Bucharest). This decision removes the management functions and auxiliary staff from the clubs that are united with the central structure [8].

As can be seen from Table 1 the most practiced sports at the level of the school structures are: athletics (in all counties - 42), football (41), handball (41), followed by volleyball (34) and basketball (31). With so much 
spread, we could call them national sports although national and international results are far from justifying large amounts of money. But here's a list of funded sports and "exotic" sports such as yachting and softball, baseball, hockey on the grass, ski jumping. These sports are not just exotic but also involve a large budget for the purchase and maintenance of equipment and, at the same time, they are also dependent on weather conditions that are not specific to our country, most of the time.

Table 1 Locations and number of sports students per branch

\begin{tabular}{llllll}
\hline $\begin{array}{c}\text { No. of } \\
\text { counties }\end{array}$ & \multicolumn{1}{c}{$\begin{array}{c}\text { Sport } \\
\text { practiced }\end{array}$} & $\begin{array}{c}\text { Students } \\
\text { reported }\end{array}$ & $\begin{array}{c}\text { No. of } \\
\text { counties }\end{array}$ & $\begin{array}{c}\text { Sport } \\
\text { practiced }\end{array}$ & $\begin{array}{l}\text { Students } \\
\text { reported }\end{array}$ \\
\hline 42 & athletics & 9094 & 11 & fencing & 653 \\
31 & basket-ball & 5369 & 9 & chess & 346 \\
41 & football & 13278 & 5 & karate & 284 \\
41 & handball & 11620 & 4 & Speed skating & 162 \\
34 & volley-ball & 6387 & 12 & rugby & 1666 \\
5 & dumb-bell & 198 & 8 & box & 310 \\
19 & natation & 3357 & 3 & sportive dance & 281 \\
24 & judo & 2224 & 4 & field hockey & 268 \\
10 & rowing & 724 & 2 & base-ball & 194 \\
9 & alpine skiing & 887 & 2 & polo & 286 \\
6 & cross-country & 622 & 2 & sport shooting & 98 \\
& skiing & & & & \\
5 & Biathlon & 368 & 2 & Ice Hockey & 336 \\
1 & ski jumps & 58 & 2 & bodybuilding & 98 \\
11 & kayak canoe & 800 & 2 & jumps into the & 81 \\
& & & & water & \\
14 & artistic & 1677 & 4 & sleigh & 156 \\
& gymnastics & & & & \\
10 & rhythmic & 762 & 2 & archery & 62 \\
& gymnastics & & & & \\
2 & aerobics & 286 & 1 & Figure Skating & 18 \\
31 & gymnastics & & & & \\
17 & wrestling & 2922 & 1 & orientation & 20 \\
13 & tennis & 866 & 1 & yachting & 17 \\
3 & table tennis & 1710 & 1 & pentathlon & 34 \\
\hline
\end{tabular}

The last centralization requested by the Ministry of National Education resulted in 70,102 registered students (Table 2) both within the LPS and within the CSS. These students are enrolled in a number of 2345 norms supported by 1937 titular teachers with related specialty. 
Marin CHIRAZI | Lumen Proceedings 12 | SEC-IASR 2019

Table 2 Number of practitioners and occupied rules

\begin{tabular}{ccc}
\hline $\begin{array}{c}\text { Total number of sports } \\
\text { students reported }\end{array}$ & $\begin{array}{c}\text { Total number of rules } \\
\text { didactic existing }\end{array}$ & $\begin{array}{c}\text { Number total } \\
\text { holders }\end{array}$ \\
\hline 70102 & 2345.04 & 1937.66 \\
\hline
\end{tabular}

Although the number of athletes may seem high, they represent $2.19 \%$ of the total number of pupils in Romania (about 3.2 million). At the same time, it should be noted that 70,102 sports students are only from the urban environment because there are no CSS in rural areas. As it can be seen, both "score 1" and "table 2" used the expression "reported sports students" because the data is extracted from an MEN request to all integrated and supplementary sports education structures. In fact, at a press conference held on April 28, 2016, the deputy director of the MEN School and University Sports Federation stated that within the sports federations belonging to the Ministry of Youth and Sports there are only 12,474 legitimate athletes who participated in official competitions [9]. This highlights the lack of transparency of data on the actual number of athletes comprised of the 2345 teaching norms within specific structures and the number of athletes actually participating in official competitions. Integrated and supplementary sports education structures are interested in "reporting" as many practical practitioners as the funding system in Romania is achieved by allocating a standardized amount to each pupil. This form of funding is available at all levels (grades 0 to XII in pre-university education, from undergraduate studies to doctoral studies in the university system) and determines the leadership of schools and teachers implicitly that the rate of advancement is as high as possible. In this sense, financial resources are allocated for the implementation of some projects at national level to reduce the dropout rate (one of the current problems of the Romanian education at all levels). The cost of such school structures is generally at least three times higher than that of an ordinary school because the budget must provide training costs (room rent, equipment, nutritional supplements, cash benefits) and participation in the competition calendar (annual visas, medical visas, travel, food, accommodation). It should be recalled that athletes do not bear the costs of attending training and competitions. A calculation of the costs related only to paying the 2345 salary fees of the mentioned structures resulted in a budget allocation of approximately 116,612,160 lei per year. We note that the report was made at the income of a long-term teacher (LPS and CSS) with a degree of differentiation and ages 1-3 years [10]. 


\section{Other sporting structures in Romania}

The first sports associations in Romania were founded in the middle of the nineteenth century. One of the first was called the "Sharing Society" (established during the reign of Al. I. Cuza) [1]. In the early years of the twentieth century, sports such as boxing, cycling, and later team games developed. The first football game was played in Timisoara in 1902, and in 1910 the first rugby club was set up in Bucharest. Two years later, the Federation of Romanian Sports Societies was established in Bucharest, followed by the establishment of the Romanian Olympic Committee in 1914 [3].After 1944 in Romania there is a sports structure under the subordination and financing of the Ministry of Sport and Youth, with a number of employed coaches as well as auxiliary and leadership staff. Currently, at the level of Romania, there are 1100 subsidized posts throughout the country through Municipal Sports Clubs at the level of each county seat [11].They are a public structure with the most varied sporting branches (the basic principle is sports that can be achieved as easily and quickly as possible - less known) that consume material and financial resources from the MTS, from the allocations of city halls of their own, as well as sponsorships. The total number of positions is centrally accounted for (MTS) and represents a budget effort amounting to a minimum of 60 million lei annually. Another category of sporting structures that emerged after 1990 and which is found in a very large number registered in the register of sports organizations (but very few) is represented by private sports clubs, where the participants (children or adults) fully bear the expenses necessary to practice. The area of spreading these structures is represented by urban agglomerations with a large school population and geographic areas that offer the possibility of practicing activities in nature (in winter in mountainous areas and in summer on the Black Sea coast).

\section{Conclusions}

Although there are numerous sources stating that the Romanian state does not allocate sufficient funds to support the practice of sport both at school and out-of-school, in reality only about 180 million lei are spent in support of the salary fund. If we think that this sum represents only the salary fund for the stated structures and there is a category of structures university sports clubs - financed by the state budget, respectively the Ministry of National Education, we can say that an important sum is allocated. 
There is a very large discrepancy in the number of students / athletes reported by each structure and the number of athletes actually legitimated, about $17.8 \%$.

Another obstacle in the organized and effective practicing of the sport by the students is the lack of the material base - sports hall. From here we can conclude that the decision to set up a sporting branch was taken into account with an effective necessity and for subjective reasons.

\section{References}

[1] Kirițescu C. Palestrica. Bucureşti: Editura Uniunii de Cultură Fizică şi Sport; 1964, pp. 61-65.

[2] Monitorul Oficial nr. 59, din 17 iunie 1923.

[3] Albu V. Istoria educaţiei fizice şi sportului. Constanţa: Editura Ex Ponto; 1996. $82 \mathrm{p}$.

[4] Ordinul M.E.C. nr.3638 / 11.04.2001.

[5] Ministerul Educației, Cercetării, Tineretului şi Sportului. (2011). Ordin nr. 5.570 din 7 octombrie 2011 privind aprobarea Regulamentului de organizare şi funcționare unită de învățământ cu program sportiv suplimentar publicat în Monitorul Oficial 792 din 8 noiembrie 2011.

[6] Parlamentul Romaniei. (2020). Lege nr. 69 din 28 aprilie 2000 educaţiei fizice şi sportului Publicat în Monitorul Oficial nr. 200 din 9 mai 2000.

[7] Stoian I. Periodic Testing - A Prerequisite for an Exact Determination of Physical Training Standards. The European Proceedings of Social \& Behavioural Sciences; 2018 pp. 318-324. Available from: http://dx.doi.org/10.15405/epsbs.2018.03.42

[8] Anexa nr. 2 la O. MEN nr. 3393 / 28.02.2017.

[9] http://www.prosport.ro/alte-sporturi/drama-nationala.

[10] Parlamentul României. (2017). Lege-Cadru Nr. 153/2017 din 28 iunie 2017 privind salarizarea personalului plătit din fonduri publice publicată în Monitorul Oficial nr. 492 din 28 iunie 2017. Available from: https://static.anaf.ro/static/10/Anaf/legislatie/L_153_2017.pdf.

[11] Ministerul Tineretului şi sportului. Retrieved from: www.mts.ro. 